Dikirim: 28 Desember 2015 Diterbitkan: 1 Juli 2016

\section{Aktivitas fisik dan konsumsi camilan pada remaja obesitas di pedesaan dan perkotaan Kabupaten Bantul}

\section{Physical activities and snack consumption of rural and urban obese adolescents in Bantul}

Mellia Silvy Irdianty ${ }^{1}$, Toto Sudargo ${ }^{2}$, Mohammad Hakimi ${ }^{1}$

\begin{abstract}
Purpose: This study aimed to determine the difference of physical activity and snack consumption of obese adolescents in urban and rural areas in Bantul. Methods: A case control study was conducted, involving 124 adolescents. Cases were obese adolescents diagnosed at screening, while the controls were not obese adolescents. Chi-square, t-test and logistic regression tests were used in the statistical analysis. Results: Adolescents who do light physical activities had 5 times greater risk of being obese than those who do normal physical activity. The kinds of snacks and obesity had a significant correlation. There were differences of means in snack weight and snack intake in obese adolescents. Conclusion: The low physical activity, high snack frequency, type of fried foods, snack weight, and snack intake were the most likely factors to increase the incidence of obesity.
\end{abstract}

Keywords: physical activity; consumption of snacks; obesity; teenagers

\footnotetext{
${ }^{1}$ Departemen Biostatistik, Epidemiologi, dan Kesehatan Populasi, Fakultas Kedokteran, Universitas Gadjah Mada (Email: silvy.irdianty@gmail.com)

${ }^{2}$ Departemen Gizi dan Kesehatan, Fakultas Kedokteran, Universitas Gadjah Mada
} 


\section{PENDAHULUAN}

Proporsi obesitas pada anak dan remaja meningkat drastis dalam dekade terakhir. Obesitas pada anak dan remaja di Amerika Serikat lebih banyak terjadi pada kelompok usia 12-19 tahun. Sedangkan, di Indonesia, prevalensi gemuk lebih banyak ditemukan pada remaja usia 16-18 tahun yaitu sebanyak 7,3\% yang terdiri dari 5,7\% gemuk dan 1,6\% obesitas. Prevalensi tersebut mengalami peningkatan dari 1,4\% (2007) menjadi 7,3\% (2013). Yogyakarta merupakan salah satu provinsi di Indonesia dengan prevalensi obesitas remaja di atas angka nasional. Prevalensi obesitas tertinggi di Kota Yogyakarta yaitu sebesar 6\% (1).

Obesitas disebabkan-ketidakseimbangan jumlah energi masuk dengan energi dikeluarkan setiap hari. Kelebihan akumulasi lemak dalam jaringan adipos diakibatkan dari hasil konsumsi makanan dan minuman berlebihan. Selain itu, perubahan gaya hidup menjadi perilaku sedentarian berkontribusi terhadap kejadian obesitas. Hal ini bisa dilihat dari kuantitas waktu menonton TV, peningkatan jumlah mobil per keluarga sehingga terjadi penurunan aktivitas fisik. Transisi yang terjadi adalah perubahan gaya hidup. Faktor inactivity berpengaruh pada perkembangan obesitas dibandingkan makan berlebihan $(2,3)$.

National Youth Physical Activity and Nutrition Study (NYPANS) menyatakan bahwa siswa memiliki akses yang mudah untuk mengonsumsi makanan dan minuman kurang sehat di lingkungan sekolah. Konsumsi camilan dan makanan cepat saji memiliki lebih sedikit porsi sayuran, kandungan kalsium yang lebih rendah, dan menyebabkan peningkatan berat badan di kalangan remaja (4-6).

Prevalensi obesitas di daerah urban sangat tinggi karena populasi ini cenderung memiliki status sosial ekonomi rendah dan paling terlayani oleh sistem perawatan kesehatan (7). Hasil survei Riskesdas 2013 menunjukkan bahwa prevalensi tertinggi obesitas di Provinsi Yogyakarta terletak di Kota Yogyakarta sebanyak 12,9\% gemuk dan $6 \%$ obesitas sedangkan Kabupaten Bantul 7,9\% gemuk dan 1\% obesitas, sementara 42,1\% penduduk usia produktif di Provinsi Yogyakarta kurang melakukan aktivitas fisik. Proporsi orang yang kurang aktivitas fisik di daerah pedesaan dan perkotaan kini tidak jauh berbeda (8). Penelitian mengenai aktivitas fisik dan konsumsi camilan pada remaja di Provinsi Yogyakarta masih belum banyak diteliti, oleh karena itu perlu dilakukan penelitian dengan tujuan untuk mengetahui hubungan aktivitas fisik dan konsumsi camilan pada remaja obesitas di daerah perkotaan dan pedesaan di Kabupaten Bantul.

\section{METODE}

Penelitian ini menggunakan rancangan kasus kontrol. Kelompok kasus adalah remaja SMA obesitas dengan nilai Indeks Massa Tubuh (IMT) $\geq 27 \mathrm{~kg} / \mathrm{m}^{2}$, sedangkan kelompok kontrol adalah remaja SMA yang tidak mengalami obesitas. Penelitian dilakukan di empat SMA negeri di Kabupaten Bantul: SMA 1 Bantul, SMA 2 Bantul, SMA 1 Jetis, dan SMA 1 Pleret. Alasan pemilihan lokasi karena peneliti ingin mengetahui perbandingan kasus obesitas di kota (diwakili dengan SMA 1 Bantul dan SMA 2 Bantul) dan di desa (diwakilkan oleh SMA 1 Jetis dan SMA 1 Pleret).

Penelitian dilakukan bulan Mei-Juni 2015 melibatkan 124 siswa. Variabel bebas adalah aktivitas fisik, konsumsi camilan (frekuensi camilan, jenis camilan, berat camilan dan asupan camilan). Variabel terikat adalah obesitas. Variabel luar adalah usia, jenis kelamin, perilaku sedentari, riwayat kegemukan dan uang jajan sehari. Uji statistik yang akan digunakan adalah chi-square, t-test, dan regresi logistik dengan confidence interval (CI) $95 \%$ serta nilai kemaknaan $\mathrm{p}<0.05$

\section{HASIL}

Tabel 1 menunjukkan sebagian besar responden berusia 18 tahun, berada pada kelas XII dan berjenis kelamin perempuan. Hampir seluruh responden memiliki perilaku sedentari tinggi dan memiliki proporsi riwayat kegemukan orang tua yang hampir sama antara orang tua obesitas dan non obesitas. Sosial ekonomi kaya mendominasi sebagian besar responden, hal ini sejalan dengan persentase uang saku yang dimiliki responden hampir seluruhnya memiliki uang saku (>=10.000 rupiah) yaitu sebanyak $79.8 \%$.

Tabel 1. Karakteristik subjek penelitian

\begin{tabular}{lll}
\hline \multicolumn{1}{c}{ Variabel } & $\mathbf{n}$ & $\mathbf{\%}$ \\
\hline Usia & & \\
16 tahun & 25 & 20.16 \\
17 tahun & 40 & 32.16 \\
18 tahun & 59 & 47.58 \\
Jenis kelamin & & \\
Pria & 50 & 40.3 \\
Wanita & 74 & 59.7 \\
Perilaku sedentari & & \\
Tinggi & 117 & 94.3 \\
Rendah & 7 & 5.7 \\
Riwayat gemuk & & \\
Obesitas & 61 & 49.2 \\
Tidak obesitas & 63 & 50.8 \\
Uang saku & & 79.8 \\
$>=10.000$ & 99 & 20.2 \\
<10.000 & 25 & \\
\hline
\end{tabular}


Penelitian ini menunjukkan hubungan bermakna secara praktis dan statistik antara aktivitas fisik dengan obesitas. Obesitas lebih banyak dijumpai hampir 5 kali lebih besar pada remaja dengan aktivitas fisik ringan di bandingan dengan remaja dengan aktivitas fisik sedang. Jenis camilan dan obesitas juga memiliki hubungan yang bermakna secara statistik dan praktis, yaitu obesitas banyak di temukan sebanyak 2 kali lebih besar pada remaja dengan konsumsi camilan goreng dibandingkan dengan remaja yang mengkonsumsi camilan non goreng (Tabel 2).

Tabel 2. Analisis chi-square hubungan antara variabel aktivitas fisik, frekuensi camilan, berat camilan, jenis camilan dan asupan camilan dengan obesitas

\begin{tabular}{|c|c|c|c|c|c|c|c|}
\hline \multirow{3}{*}{ Variabel } & \multicolumn{4}{|c|}{ Obesitas } & \multirow{3}{*}{$\chi^{2}$} & \multirow{3}{*}{ OR } & \multirow{3}{*}{$95 \%$ CI } \\
\hline & \multicolumn{2}{|c|}{ Obesitas } & \multicolumn{2}{|c|}{ Tidak } & & & \\
\hline & $\mathrm{n}$ & $\%$ & $\mathrm{n}$ & $\%$ & & & \\
\hline \multicolumn{8}{|l|}{ Aktivitas fisik } \\
\hline Ringan & 47 & 75.8 & 24 & 38.7 & 17.43 & 4.96 & $2.14-11.63$ \\
\hline Sedang (R) & 15 & 24.2 & 38 & 61.3 & & & \\
\hline \multicolumn{8}{|l|}{$\begin{array}{l}\text { Frekuensi } \\
\text { camilan }\end{array}$} \\
\hline Sering & 35 & 56.4 & 32 & 51.6 & 0.29 & 1.21 & $0.56-2.61$ \\
\hline $\begin{array}{l}\text { Kadang }(\mathrm{R}) \\
\text { Jenis camilan }\end{array}$ & 27 & 43.6 & 30 & 48.4 & & & \\
\hline Gorengan & 52 & 83.9 & 35 & 56.4 & 11.13 & 2.21 & $1.26-3.85$ \\
\hline $\begin{array}{l}\text { Non gorengan } \\
\text { (R) }\end{array}$ & 10 & 16.1 & 27 & 43.6 & & & \\
\hline
\end{tabular}

Tabel 3 menunjukkan perbedaan rata - rata antara berat camilan dan asupan camilan pada remaja obesitas dan non obesitas. Rata - rata remaja obesitas memiliki konsumsi berat camilan 121 gram per hari dengan jumlah asupan dari camilan hampir $70 \%$.

Tabel 3. Hasil uji T variabel berat camilan (gram) dan asupan camilan antara remaja obesitas dan nonobesitas

\begin{tabular}{lccccc}
\hline \multicolumn{1}{c}{ Variabel } & \multicolumn{1}{c}{ Obesitas } & $\begin{array}{c}\text { Non } \\
\text { Obesitas }\end{array}$ & Mean & 95\%CI & $\boldsymbol{p}$ \\
& \multicolumn{1}{c}{$\begin{array}{c}\text { Mean } \pm \text { S Mean } \pm \text { S } \\
\text { D }\end{array}$} & Diff \\
& $\mathbf{D}$ & & & \\
\hline Berat camilan & $121 \pm$ & $63.9 \pm 3.7$ & 57.07 & $41.61-72$. & 0.000 \\
(gram) & 68.6 & 3 & & 53 & \\
Asupan & $61.93 \pm 3$. & $55.09 \pm 2$. & 6.83 & $53.97-63$. & 0.000 \\
camilan (\%) & 53 & 88 & & 05 & \\
\hline
\end{tabular}

Model 2 dipilih sebagai model yang baik untuk menjelaskan hubungan konsumsi camilan dan aktivitas fisik dengan obesitas dengan mempertimbangkan semua variabel bermakna terhadap kejadian obesitas. Model 2 menunjukkan besar hubungan variabel bebas (aktivitas dan frekuensi camilan, berat camilan, jenis camilan dan asupan camilan) dengan variabel terikat (obesitas) di sertai dengan variabel riwayat kegemukan orang tua. Hasil analisis menunjukkan peningkatan OR-crude pada variabel aktivitas fisik, frekuensi camilan dan penurunan nilai OR pada variable jenis camilan. Penurunan dan kenaikan mengalami perubahan secara signifikan setelah ditambahkan variabel riwayat kegemukan orang tua ke dalam model. Riwayat kegemukan mengubah efek risiko aktivitas fisik ringan, berat camilan per hari, pemilihan jenis camilan goreng, serta asupan. aktivitas fisik, frekuensi camilan, berat camilan, jenis camilan dan asupan camilan dan jenis kelamin berkontribusi terhadap kejadian obesitas sebesar 50 \% (Tabel 4.).

Tabel 4. Model analisis regresi logistik

\begin{tabular}{lcc}
\hline & \multicolumn{2}{c}{ Obesitas } \\
\cline { 2 - 3 } Variabel & Model 1 & Model 2 \\
& OR & OR \\
\hline Aktivitas fisik & $\mathbf{9 5 \%}$ CI & $95 \%$ CI \\
Ringan & 5 & 7.06 \\
Sedang(R) & $(1.74-14.37)$ & $(2.17-22.94)$ \\
Frekuensi camilan & 1 & 1 \\
Sering & & \\
Kadang(R) & 3.28 & 4.04 \\
Berat camilan & $(1.07-10.04)$ & $(1.19-13.67)$ \\
Jenis camilan & 1 & 1 \\
Gorengan & 1.04 & 1.04 \\
Non gorengan(R) & $(1.02-1.06)$ & $(1.02-1.06)$ \\
Asupan camilan & & \\
Riwayat gemuk & $1.28-12.65)$ & $(1.14-14.00)$ \\
Ya & 1 & 1 \\
Tidak(R) & $(0.99-1.02)$ & 1.00 \\
R & & $(0.99-1.02)$ \\
Deviance & & 0.15 \\
n & & $(0.04-0.5)$ \\
\hline
\end{tabular}

\section{BAHASAN}

Obesitas disebabkan banyak faktor baik secara biologis maupun lingkungan. Beberapa penelitian menyebutkan bahwa faktor yang berkontribusi besar terhadap obesitas adalah pola konsumsi makanan yang salah dan perubahan aktivitas fisik. Pada tahun 1977 hingga 1996 persentase remaja yang mengonsumsi camilan meningkat dari $76 \%$ ke $88 \%$. Terjadi penurunan aktivitas fisik antara tahun 1969 hingga tahun 2001, persentase siswa yang bersepeda dan jalan ke sekolah menurun dari 41,6\% menjadi $26,4 \%$. Hal ini disebabkan karena perubahan gaya hidup ke arah sedentary life (4).

Secara umum karakteristik responden adalah remaja dengan usia 16 tahun hingga 18 tahun. Sebagian 
besar kejadian obesitas dialami oleh siswa yang berusia 18 tahun dan duduk di kelas XII. Peneliti menetapkan subyek penelitian dengan kriteria tersebut karena pada usia 16 hingga 18 tahun, remaja berada dalam masa remaja pertengahan. Dimana, pada masa remaja pertengahan, kelompok remaja cenderung rentan terhadap kebutuhan gizi terutama gizi berlebih. Usia merupakan salah satu faktor yang berkontribusi terhadap kejadian obesitas. Semakin bertambah usia seseorang, akan meningkatkan risiko bertambah massa lemak dalam tubuh. Hal ini sejalan dengan penelitian yang dilakukan oleh Martin dan Marinho yang menyatakan bahwa semakin bertambahnya usia akan meningkatkan penumpukan lemak dalam tubuh, khususnya pada bagian-bagian lemak sentral (9). Setelah usia 20-30 tahun, massa otot tubuh menurun dan massa lemak akan meningkat hingga mencapai usia 60-70 tahun (10). Hal ini dipertegas oleh Murage, Kahn, bahwa odd ratio obesitas meningkat $10 \%$ setiap peningkatan satu kelompok usia (11).

Semakin tinggi kelas pendidikan yang ditempuh seseorang meningkatkan risiko terjadinya obesitas. Pernyataan tersebut dipertegas dengan penelitian ysebelumnya yang menyatakan kejadian obesitas meningkat setara dengan peningkatan pendidikan (12). Hasil uji chi-quare menunjukkan adanya hubungan yang bermakna antara aktivitas fisik dan obesitas. Remaja dengan aktivitas fisik ringan akan berpeluang 4 kali lebih besar mengalami obesitas dibandingkan dengan remaja dengan aktivitas fisik sedang. Pada penelitian ini mayoritas siswa memiliki pola aktivitas fisik sedang. Remaja usia 16 - 18 lebih disibukkan dengan kegiatan sekolah dan bermain dengan teman sebaya. Aktivitas fisik sedang yang rutin dilakukan oleh sebagian besar responden adalah kegiatan rutin setelah pulang sekolah seperti membersihkan diri, membersihkan kamar, membantu orang tua menyapu, mengepel, dan terkadang memasak di rumah. Bentuk aktivitas fisik sedang dapat dijumpai pada kegiatan ekstrakurikuler seperti pramuka, paduan suara, dan kegiatan yang lain yang dilakukan di sekolah. Sebagian besar responden pada penelitian ini adalah siswa kelas XII, dan sudah tidak mengikuti kegiatan ekstrakurikuler maupun kegiatan sekolah lainnya, sehingga hal tersebut menjadi pemicu berkurangnya aktivitas fisik pada siswaaktivitas fisik yang kurang pada remaja berkontribusi besar terhadap kejadian obesitas. Remaja dengan aktivitas terbatas akan mengalami ketidakseimbangan energi ke arah positif sehingga mengarah pada penyimpanan energi dan penambahan berat badan. Penelitian ini sejalan dengan penelitian Ortega,
Ruiz bahwa anak-anak dan remaja dengan tingkat aktifitas fisik rendah lebih berisiko mengalami overweight atau obesitas serta memiliki risiko tinggi terhadap lingkar pinggang yang lebih besar (13), sedangkan rekomendasi aktivitas fisik untuk anak usia 5-18 tahun adalah melakukan aktivitas fisik sedang hingga berat minimal 60 menit setiap hari (14).

Penelitian ini menunjukkan bahwa sebagian besar subyek memiliki frekuensi konsumsi camilan lebih dari 4 kali dalam seminggu baik remaja di pedesaan maupun di perkotaan. Hal ini menunjukkan bahwa secara menyeluruh remaja menyukai kebiasaan mengonsumsi camilan. Kebiasaan mengonsumsi camilan dengan frekuensi sering memiliki kontribusi besar dalam peningkatan massa lemak dalam tubuh. Kondisi ini menjadi semakin buruk dengan jenis camilan yang dikonsumsi remaja biasanya camilan dengan kandungan tinggi gula dan lemak. Hal ini sesuai dengan penelitian sebelumnya yang menunjukkan remaja yang memiliki frekuensi konsumsi camilan sebanyak dua hingga empat kali dalam sehari lebih berisiko mengalami obesitas (15).

Frekuensi konsumsi camilan yang tinggi seringkali didukung oleh sebuah kebiasaan yaitu menonton televisi atau penggunaan gadget di waktu senggang. Remaja yang suka menonton televisi ataupun menggunakan alat elektronik lain memiliki kecenderungan mengonsumsi camilan yang lebih tinggi dengan kandungan tinggi lemak dan gula. Kebiasaan ini seringkali dijumpai terutama oleh pada remaja putri. Semakin tinggi frekuensi konsumsi camilan maka asupan lemak juga akan meningkat (15). Pemilihan jenis camilan tidak sehat dapat menyebabkan obesitas pada remaja. Remaja yang suka mengonsumsi camilan tinggi gula dan lemak memiliki risiko lebih mengalami obesitas. Beberapa penelitian menyebutkan camilan sebagai makanan yang tidak sehat. Camilan yang dimaksud adalah makanan yang tinggi gula, tinggi lemak tetapi rendah serat. Makanan tersebut memberikan sumbangan yang besar terhadap asupan kalori dan kolesterol dalam sehari (16). Hasil penelitian ini sejalan dengan penelitian sebelumnya yang menemukan remaja yang mengonsumsi makanan tinggi gula dan lemak memiliki risiko 5,74 kali mengalami obesitas (16). Kebiasaan jajan di luar merupakan sebuah kebiasaan yang dapat meningkatkan konsumsi energi tubuh yang berakibat pada peningkatan kejadian obesitas. Peningkatan obesitas seiring dengan peningkatan frekuensi makan di luar dalam jumlah besar. Frekuensi dan jumlah camilan memengaruhi pening- katan energi dalam sehari (17). Makanan gorengan mengandung 4-14\% dari total beratnya, sehingga semakin besar berat 
gorengan, semakin banyak lemak yang dikonsumsi (18). Obesitas banyak ditemukan dua kali lebih besar pada siswa yang suka mengonsumsi camilan goreng dibandingkan dengan siswa yang mengonsumsi camilan non-goreng. Jenis camilan yang digoreng dengan minyak mengandung asam lemak jenuh. Apabila camilan ini dikonsumsi dalam jumlah besar setiap hari akan dimetabolisme tubuh dan meningkatkan lemak dalam tubuh. Camilan yang mengandung lemak jenuh meningkatkan kadar kolestrol darah sebanyak 15 - 25\% (19).

\section{SIMPULAN}

Hubungan antara aktivitas fisik, frekuensi camilan, berat camilan, jenis camilan dan asupan camilan denganobesitas disertai dengan variabel jenis kelamin dan riwayat kegemukan memberikan kontribusi terhadap kejadian obesitas sebesar 50 \%. Aktivitas fisik ringan lebih banyak ditemukan pada remaja obesitas dibandingkan dengan remaja non-obesitas. Remaja dengan aktivitas fisik ringan berpeluang hampir 5 kali lebih besar mengalami obesitas dibanding dengan remaja dengan aktivitas fisik berat. Konsumsi camilan jenis gorengan menyebabkan remaja berpeluang 2 kali lebih besar mengalami obesitas dibandingkan dengan konsumsi camilan non goreng. Terdapat perbedaan yang bermakna antara berat camilan dan asupan camilan remaja obesitas dan non obesitas.

Orangtua perlu memperhatikan dan memantau pola konsumsi remaja dan memberikan contoh pola konsumsi yang sehat. Bagi sekolah, disarankan untuk mencanangkan kantin sehat dengan mengelola dan mengawasi makanan dan minuman yang disediakan. Bagi remaja, disarankan untuk menjaga pola konsumsi seimbang dan rutin beraktivitas fisik seperti olahraga untuk mencegah obesitas.

\footnotetext{
Abstrak

Tujuan: Penelitian ini bertujuan untuk mengetahui perbedaan aktivitas fisik dan konsumsi camilan pada remaja obesitas di daerah pedesaan dan perkotaan di Kabupaten Bantul. Metode: Penelitian ini menggunakan rancangan penelitian case control, dengan populasi remaja sekolah menengah atas (SMA) negeri di Kabupaten Bantul. Kelompok Kasus adalah remaja yang didiagnosis obesitas pada tahap skrining, sedangkan kelompok kontrol adalah remaja dengan berat badan normal. Analisis data menggunakan uji chi-square dan uji-t dan $n$ uji regresi logistik. Hasil: Remaja dengan aktivitas fisik
}

ringan memiliki peluang hampir 5 kali lebih besar mengalami obesitas dibandingkan remaja dengan aktivitas fisik sedang (OR 4,96 (CI 95\%:2.14 -11.63). Hubungan antara jenis camilan dan obesitas juga memiliki hubungan yang bermakna secara statistik dan praktis, yaitu obesitas banyak di temukan sebanyak 2 kali lebih besar pada remaja dengan konsumsi camilan goreng dibandingkan dengan remaja yang mengonsumsi camilan non-goreng. Terdapat perbedaan rerata berat dan asupan camilan pada remaja obesitas dan non-obesitas. Simpulan: Aktivitas fisik ringan, frekuensi camilan tinggi, jenis camilan gorengan, berat camilan dan asupan camilan tinggi berpeluang lebih besar meningkatkan obesitas remaja.

Kata kunci: aktivitas fisik; konsumsi camilan; obesitas; remaja

\section{PUSTAKA}

1. NHNES. Healty Weight, Overweight, and Obesity Among US Adults: CDC; 2012.

2. Hartono A. Gizi Kesehatan Masyarakat. Jakarta: EGC; 2009.

3. Huriyati E. Aktivitas Fisik pada Remaja SLTP di Kota Yogyakarta dan Kabupaten Bantul serta Hubungannya dengan Kejadian Obesitas. 2004.

4. Brener ND, Eaton DK, Kann LK, McManus TS, Lee SM, Scanlon KS, et al. Behaviors related to physical activity and nutrition among US high school students. Journal of Adolescent Health. 2013;53(4):539-46.

5. Larson NI, Story M, Wall M, Neumark-Sztainer D. Calcium and dairy intakes of adolescents are associated with their home environment, taste preferences, personal health beliefs, and meal patterns. Journal of the American Dietetic Association. 2006;106(11):1816-24.

6. Niemeier HM, Raynor HA, Lloyd-Richardson EE, Rogers ML, Wing RR. Fast food consumption and breakfast skipping: predictors of weight gain from adolescence to adulthood in a nationally representative sample. Journal of Adolescent Health. 2006;39(6):842-9.

7. Joens-Matre, Welk, Calabro M.A, Russell D.W, Niklay E, Hensley L.D. Rural - Urban Differences in Phusical Activity, Physical Fitness, and Overweight Prevalence of Children. J Rural Health. 2008;24 ::49 $-54$.

8. Kemenkes RI. Riskesdas Dalam Angka Provinsi Daerah Istimewa Yogyakarta 2013. Jakarta: Lembaga Penerbitan Badan Litbangkes 2013.

9. Martin IS, Marinho SP. The Potential of Central Obesity Antropometric Indicators As Diagnostic Tools. Revista de Saude Publica. 2003;37(6):1-13.

10. Villareal DT, Apovian CM, Kushner RF, Klein S. Obesity in Older Adults Review and POsition of Amerocan Society for Nutrition and NAASO, the Obesity of Society. The American journal of clinical nutrition. 2005;82:923 - 34. 
11. Murage E, Kahn K, Pettifor J, Tollman S, Grobusch K, Norris S. Predictors of adolescent Weight Status and Central Obesity in Rural South Africa. Public Health Nutrition. 2011;14(6):1114-22.

12. Silva D, Andreia P, Joao S, Edio P. Epidemiology of Abdominal Obesity among Adolescent from Brazilian State Capital. Journal Korean Med Sci. 2011;26(78 - 84).

13. Ortega F, Ruiz J, Sjostrom M. Physical Activity, Overweight and Central Obesity in Swedish Children and Adolescents : The European Youth Heart Study. Int $\mathrm{J}$ Behav Nutr Phys Act. 2007;4(1):61-71.

14. Strong WB, Malina RM, Blimkie CJR, Daniels SR, Dishman RK, Gutin, B, Hergenroeder AC, et al. Evidence Based Physical Activity For School Age Youth. Journal of Pediatric Health Care. 2005;146:732-7.

15. Keast DR, Nicklas TA, O'Neil CE. Snacking is associated with reduced risk of overweight and reduced abdominal obesity in adolescents: National Health and Nutrition Examination Survey (NHANES) 1999-2004. The American journal of clinical nutrition. 2010;92(2):428-35.

16. Ezmaillzadeh A, Azadbakht L. Major Dietary Pattern in Relation to General Obesity and Central Adiposity Among Iranian Women. The Journal of nutrition. 2008;182(2):358-63.

17. Pontes L, Sousa M, Lima R. Dietetic Profile, Nutritional Status and Prevalence of Central in Recreative Soccer Practituoners. Rev Bras Med Exporte. 2006;12(4):180e-3e.

18. Yusuf F, Sirajuddin S, Najimuddin U. Analisa Kadar lemak Jenuh dalam Gorengan dan MInyak Bekas Hasil Penggorengan Makanan Jajanan di LIngkungan Workshop Universitas Hasanuddin. 2013.

19. Guyton A, Hall J. Buku Ajar Fisiologi Kedokteran. Jakarta: EGC; 2008. 